\title{
Semantic Classification of Russian Alternative Place-Name Etymologies from Trediakovsky's Three Discourses on Three Most Important Russian Antiquities
}

\author{
Alexander V. Kalashnikov \\ National Research University "Higher School of Economics" \\ Moscow, Russian Federation
}

Abstract

The research addresses the etymologies of 82 toponyms proposed by the Russian scholar V. Trediakovsky in the mid1700s book Three Discourses on Three Most Important Russian Antiquities compared with 148 etymologies of the toponyms from The Etymological Dictionary of the Russian Language by M. Vasmer, where the etymologies had been identified under the modern etymological approach. The article argues that the alternative etymologies proposed by Trediakovsky and the toponymic etymologies having been established under linguistic principles possess similarities in terms of general semantic features. Identifying the semantic features of toponyms from the two selections required the classification based on etymological and semantic features, with the principal division into natural and cultural place-names. The research showed that 5 out of 7 semantic features: hydronym, choronym, people's activity, ethnonym, and type of settlement, corresponded in both selections. The alternative etymologies from the discourses revealed more semantic features related to the climate and soil. The semantic features of flora and fauna, which are part of modern semantic classifications, were found in rare cases in both toponymicons. The research showed that although generally Trediakovsky's etymologies seemed to contradict the existing linguistic principles, the semantic features remained comparable with those of the place-name etymologies that were compiled at the later stages of scientific thought.

Keywords

historical linguistics, alternative etymology, toponymicon, Trediakovsky

For citation

Kalashnikov, Alexander V. Semantic Classification of Russian Alternative Place-Name Etymologies from Trediakovsky's Three Discourses on Three Most Important Russian Antiquities. Vestnik NSU. Series: Linguistics and Intercultural Communication, 2021, vol. 19, no. 1, p. 81-91. DOI 10.25205/1818-7935-2021-19-1-81-91

\section{Семантическая классификация топонимов с альтернативной этимологией из «Трёх рассуждений о трёх главнейших древностях российских» В. К. Тредиаковского}

\author{
А. В. Калашников \\ Национальный исследовательский университет «Высшая школа экономики» \\ Москва, Россия
}

Аннотация

Исследование посвящено этимологическим значениям 82 топонимов, предложенным В. К. Тредиаковским в «Трёх рассуждениях о трёх главнейших древностях российских» в середине XVIII в., в сопоставлении с этимологическими значениями 148 топонимов из «Этимологического словаря русского языка» М. Фасмера, в котором этимологические значения устанавливались в соответствии с современными методами этимологии. В статье утверждается, что альтернативные этимологические толкования топонимов Тредиаковского обладают общими семантическими признаками с этимологией топонимов, выявленной в соответствии с принятыми

(C) А. В. Калашников (А. V. Kalashnikov), 2021 
в лингвистике принципами. Для выявления такого сходства в статье предложена классификация семантических признаков относительно этимологии топонимов, основанная на признаках природного и культурного ландшафта. Исследование показало, что 5 из 7 семантических признаков: гидроним, хороним, деятельность людей, этноним и тип поселения, были представлены в обеих выборках. Несколько большее число семантических признаков природного ландшафта, таких как почва и климат, были обнаружены среди случаев альтернативной этимологии. Семантические признаки флора и фауна, входящие в современные семантические классификации топонимов, были обнаружены только в единичных случаях в обоих топонимиконах. Исследование показало, что, хотя Тредиаковский предлагал объяснения географических названий, в достаточной степени противоречащие лингвистическим принципам, семантические признаки топонимов в его книге тематически сопоставимы с этимологией топонимов, изучавшихся на более поздних этапах развития науки.

Ключевые слова

историческая лингвистика, альтернативная этимология, топонимика, Тредиаковский

Для ицитирования

Kalashnikov, Alexander V. Semantic Classification of Russian Alternative Place-Name Etymologies from Trediakovsky's Three Discourses on Three Most Important Russian Antiquities // Вестник НГУ. Серия: Лингвистика и межкультурная коммуникация. 2021. Т. 19, № 1. С. 81-91. DOI 10.25205/1818-7935-2021-19-1-81-91

\section{Introduction}

Vasily Trediakovsky (1703-1769), a poet and translator, is not generally known as an etymologist and historian. However, being also the secretary of the Saint Petersburg Academy of Sciences, he claimed himself to be the follower of the French historian Ch. Rollin whose Ancient History was translated by Trediakovsky into Russian. His Three Discourses on Three Most Important Russian Antiquities (hereafter discourses) in which the origins of place-names were instrumental in asserting the primacy of the Slovensky (Slavic) language as being older compared to many other languages and hence claiming its supremacy. In its turn, the Russian language, referred to as Slavensky in the book, was considered to be its closest successor. A special feature of the discourses was that they contained an extensive collection of place-name etymologies, while other works on history of that time provided such explanations only occasionally [Schoettgenius, 1730; Lomonosov, 1952; Tatishchev, 1994]. Despite the disputable etymologies, called alternative in the article, Trediakovsky, as well as Lomonosov, may be regarded as the forerunner of the comparative method in Russian linguistics, which is why Trdiakovsky's discourses, especially On the Primacy of the Slavic Language to Teutonic, are sometimes viewed as the first Russian work on linguistics [Klubkov, 2002. P. 59].

The research argues that Trediakovsky's etymological approach has some similarities with the modern toponymic etymology, which is seen in the correspondence of the semantic features of the appellatives involved in the etymological studies. The concept of alternative etymology used in the article refers to the etymology which is either not accepted in linguistics or the etymological analysis that is not carried out properly. At that the existing terms such as folk etymology associated with alternative etymology, is not unanimously accepted [Dalberg, 2008. P. 80, 83]. While folk etymology relies on popular world-view in the interpretations of words, Trediakovsky proposed his own etymological versions that he considered to be correct. The research will determine the semantic features applied in alternative etymology compared with the toponymicon from the four-volume academic etymological dictionary [Vasmer, 1986] (hereafter dictionary). The relevance of the research is in contributing to place-name etymology and the early development of etymology, which is significant, especially with regard to the interest in the $19^{\text {th }}$ century Russian lexicology [Reyfman, 1990. P. 236] and the recent spread of alternative etymology as part of nationalist fringe theories and alternative chronologies [Fomenko, Nosovsky, 2010]. The novelty of the study is that this is the first research on Trediakovsky's etymologies within toponymic domain. The extensive selection of toponymic alternative etymologies has not been analyzed in the context of academic etymological research and semantic classifications. In particular, the numerous semantic classifications of the $20^{\text {th }}$ and $21^{\text {st }}$ centuries reviewed by J. Tent and D. Blair [Tent, Blair, 2009] did not examine etymology. To accomplish the introduction, we will specify the delimitations of the research. They concern the 
focus made on place names, while the discourses and the dictionary contained a number of etymologies for other proper names as well.

\section{Review of Trediakovsky's discourses and literature review}

The discourses, a less known work on Russian etymology and linguistics, deserve special reviewing as part of literature associated with early Indo-European languages. In particular, the monograph by Eco [Eco, 1995] on the historical theories of the primordial language did not mention Trediakovsky's work. The title of the discourses collected in a single volume is Three Discourses on Three Most Important Russian Antiquities, namely: 1. On the Primacy of the Slovyansky Language to Teutonic. 2. On the Origins of the Rus' People. 3. On the Varangians as Slavic Russian People, their Title, Genesis and Language (Три разсуждения о трех главнейших древностях российских, а именно: I. О первенстве словенскаго языка пред тевтоническим. II. O первоначалии россов. III. О варягах руссах славянскаго звания, рода и языка) [Trediakovsky, 1849]. The book, written in 1757, was published posthumously in 1773 . The discourses have been republished in a modern adaptation accompanied by commentaries [Trediakovsky, 2013].

The discourses are a valuable collection of the references to the sources on the pre-Christian Russian history and the characteristics of the $18^{\text {th }}$ century writing on linguistics. It is worth pointing to Trediakovsky's awareness of the views of the primordial language as the discourses referred to G. Hensel's Synopsis Universae Philologiae [Trediakovsky, 1849. P. 466], Rudbeck's treatise Atlantis [Ibid. P. 483], Leibniz [Ibid. P. 444] and Goropius Becanus [Ibid. P. 353]. The general quest for a shared ancestral language was in line with other conceptions common in the Enlightenment period. In particular, O. Rudbeck speculated on the primacy of Swedish, G. Hensel asserted the primacy of Hebrew, J. Horopius Becanus viewed Dutch as the language of the Paradise [Eco, 1995].

Trediakovsky's hypothesis on a shared ancestral language was that after the confusion of tongues the Japhetic languages of the Old World stemmed from Slovensky. Trediakovsky considered Russian to be the direct and closest successor of the Slavic language, unlike other European languages which originated in the Slavic language according to Trediakovsky. Hence, he attempted to show a connection of the Slavic languages with other European languages and argued that the Russian language preceded Latin. Despite mistaken beliefs that originated from earlier historical sources, Trediakovsky followed the principle which has remained valid - tribes would transfer the place names, which is why many places were dubbed identically or similarly.

Trediakovsky's work presented the motivations of the place names in detail. First, the versions were shown from several earlier sources, then the writer drafted his own one, based on the distorted form of a place-name, e.g. Норвегия - Наверхия (Norvegiya - Naverkhiya), followed by the explanation 'because it is in the upper part' (наверxy in Russian) [Trediakovsky, 1849. P. 360]. Trediakovsky considered his own interpretations without insisting on them. His own opinion was presented by the expressions я мню 'it seems to me'; полагаю 'I suggest'; по моему 'іп ту оріnion' etc. Some of the place-name etymologies were added to the references of the discourses.

Generally, the writer applied historical facts mostly without addressing mythological events or deities. However, the references to folklore and classical mythology both for research and poetic license were found in the discourses, in particular the folk character Bova Korolevich (Prince Bova), lines from a Russian folk song, an incantation and a reference to the myth about the birth of Athena. The linguistic sources presented in the discourses were Western, some of which are little known nowadays. The authors of the referenced works dated back to the $16^{\text {th }}-17^{\text {th }}$ centuries: G. Hensel Synopsis Universae Philologiae, G. Knapski Thesaurus Polono-latino-Graecus seu Promptuarium Linguae Latinae et Graecae, B. von Faber Thesaurus Eruditionis Scholasticae, C.-P. Richelet Dictionnaire François. According to the data, to make the etymological interpretations of place-names, Trediakovsky relied on 47 ancient, medieval and contemporary authors, namely, Herodotus, Stephanus of Bizantium, Constantine VII Porphyrogenitus, J. Zonaras, M. Orbini, S. Bochart, Ch. Cellarius, G. Bayer, Ch. Schöttgen. The Russian sources mentioned in the dis- 
courses were mostly chronicles: The Nikon Chronicle (Никоновская летопись), The Tale of Bygone Years (Повесть временных лет), The Book of Degrees of the Royal Genealogy (Степенная книга), as well as The Kievan Synopsis (Киевский синопсис) claimed to be written by Gizel and The History of Scythians (Скифская история) by A. Lyzlov. Numerous academic sources had been added with occasional quotes from The Bible and classical authors, such as Horace's Ars Poetica, Sidonius' Letters, Plautus' comedy play Poenulus, Lucan's De Bello Civili. Interestingly, the historical sources were mostly foreign and did not mention Trediakovsky's peers at the St. Petersburg Academy of Sciences, such as M. Lomonosov.

The majority of the etymological commentaries of the book were concentrated in the first discourse On the Primacy of the Slavic Language to Teutonic, with additional place-name etymologies presented in the other two parts. The discourse On the Varangians as Slavic Russian People, their Title, Genesis and Language made a special focus on the Dnieper rapids, whose names have been frequently discussed in the context of the origin of the Rus' people [Schoettgenius, 1730; Tatishchev, 1994; Lomonosov, 1952]: Ne supi, Gelandri, Ulvorsy, Nejasyti, Varufors, Viruchi, Naprjazi [Entwistle, Morison, 1949. P. 174]. The place names from Trediakovsky's book may be known now though some of them are obsolete or regarded as historical: regions Batavia, Caledonia, Celtia, Gardariki, Gelvetia, Illiriya, Lusitania; towns Holmgard, Sambat, Wolin, and water features Borysthenes, Codanus sinus, Hypanis, Istros, Rudon, Tiras, Viadrus. The place-names were presented in distorted forms, making the motivation associated with the Russian general vocabulary words more evident and self-explanatory. A large share of the distortions were the insertions of letters: Блесков for Псков (Pskov), Пристания for Британия (Britain), Горло-на-Дери for Геландри (Gelandri), Срывун for Струвун (Struvun); and the omissions of letters: Овитания and Окатания for Аквитания (Aquitania), Шкодынавия for Скандинавия (Scandinavia).

Despite the fact that Trediakovsky was conscious of the necessity in a scrupulous approach when dealing with etymology [Trediakovsky, 1849. P. 325], it is likely that the lack of sufficient etymological studies at his time and the excessive focus on the comparison of words without considering grammar forms did not provide for developing place-name motivations under comparativist principles formulated in the $19^{\text {th }}$ century. Based on similar in form words and morphemes, his approach may deem fanciful nowadays, but it was relatively common up to the $19^{\text {th }}$ century. Still, the motivations considered only of a single Slavic origin made the place-name interpretations seem odd both to the contemporary and subsequent scholars.

As to the literature review for the research, the beginning of the $21^{\text {st }}$ century has seen several studies devoted to Trediakovsky: the articles, written by P. Klubkov [Klubkov, 2002], A. Rastyagaev, and Y. Slozhenkina [Rastyagaev, Slozhenkina, 2016]. P. Klubkov provided a profound general analysis of Trediakovsky's etymological principles appreciating the early attempts to develop etymology, though without focusing on place-names [Klubkov, 2002]. Thus, he compiled a list of the sound correlations in the etymologies and noted that Trediakovsky applied several etymological motivations for a name and preferred the etymologies based on general Slavic words to the origin arising from proper names. The article was concluded with the idea that Trediakovsky's etymological views were not subject to comparison with modern sources as those versions were created in the pre-etymological period of linguistics. T. Maltseva [Maltseva, 2015; 2019] mentioned the discourses in terms of the comparison of the historical views of Trediakovsky and his contemporaries M. Lomonosov and A. Sumarokov [Maltseva, 2015]. Besides, the discourses were recognized as the earliest studies against the historical conception of Normanism formulated by T. S. Bayer [Maltseva, 2019], who argued that the first Russian rulers had been Scandinavian.

The spread of etymological interpretations and criticism of etymological fallacies were common in the $18^{\text {th }}$ century. Trediakovsky showed his own persuasive negative attitude to inconsistent etymological research [Trediakovsky, 1849. P. 325].The irrelevance of etymology for historical studies, especially concerning place names was expressed, in particular by the historian A. Schlözer [Schlözer, 1809. P. 429], dubbing the approach Rudbeckian art after O. Rudbeck, the scientist Lomonosov [Lomonosov, 1952. P. 32-33], who criticized the explanations of words suggested by the 
historian T. S. Bayer, and the literary critic and ethnographer N. Nadezhdin [Nadezhdin, 1837. P. 39]. The $19^{\text {th }}$ century historian S. Solovyov showed a neutral attitude to the pre-comparativist attempts of applying etymologies for historical studies [Solovyov, 1901. P. 1356-1359]. E. Lyatsky, the author of the article Trediakovsky in The Brockhaus and Efron Encyclopedic Dictionary [Lyatsky, 1901] mentioned the writer in a biased critical way, which is seen in adding the examples of the etymologies not found in the discourses: Париж < парить (Paris < to hover), Мадрид < мyдрumb (Madrid < to be cunning).

Concerning recent etymological studies, a sufficient review of place-names and their semantic features was presented in The Oxford Handbook of Names and Naming [Hough, 2016]. The chapter by J. Kuhn [Kuhn, 2016] is concerned with the features of rural names, which made them of special relevance to this research. Thus, Kuhn proposes the division of place names into natural and cultural ones and describes the key semantic features of toponyms. The current research refined the groupings for the current classification (see the section Methods).

\section{Methods}

The methodology of the research may be outlined according to the stages: collecting the proper names discussed in each of the selections to show the share of place names among them; identifying the groups of natural and cultural place names to rank them; distributing the place names in the semantic classification and calculating the percentage for the groups within the classification to reveal the overlapping groups in the classification.

The toponymicon from the discourses is presented in a list with the motivations proposed by Trediakovsky. The place names under examination are shown with multiple versions, which is why the number of the toponymic appellatives exceeds the number of the place names in the discourses. Several place names had up to three or four motivations, in particular Britain, Germany, Aquitania, Pskov, Ulvorsy. Hence, the same place name may repeat with different appellatives in several groups of the classification and the statistics will rely on the number of the appellatives.

To collate the alternative etymology approach to the place-name etymologies construed under the principles of the comparative method, it is necessary to draft an etymology related semantic classification. For developing it, the division into groups by semantic features is made on the selection of the place names from volume 1 of the dictionary [Vasmer, 1986]. The edition serves as the counterpart created in the mid- $20^{\text {th }}$ century. The significance of the dictionary for the research was a sufficient share of place names as well as various proper names collected in the edition, while many other etymological dictionaries did not include place-name etymologies.

The selection of the place-name appellatives is made under the criterion of natural and cultural place names. Natural names also earlier known as topographical place-names [Taszycki, 1946. P. 23] "are based on natural facts and can describe the characteristics of the named object" [Kuhn, 2016. P. 137]. Cultural names "reflect human influence on the named area" [Kuhn, 2016. P. 137; see also Taszycki, 1946. P. 23]. The natural and cultural place names as collective units are referred to as the natural domain and cultural domain respectively. Though Kuhn proposed the division for rural names, it deems relevant to the discussion of the semantic features in terms of etymology.

The total semantic classification for the research includes 7 groups: 4 groups of the natural place-name domain: hydronym, choronym, climate, soil, and 3 groups of the cultural place-name domain: people's activity, ethnonym, type of settlement. The semantic feature classification of the place names was mostly based on the pattern presented in the paper by J. Kuhn [Kuhn, 2016]. The researcher specified the following features accompanied with examples: climate (the Czech name Teplice), water (the Swiss name Zwüscherwassere), animals (the French name La Loubiere), plants (the Spanish name Oliviar), soil (the German name Arschitz) [Kuhn, 2016. P. 137-138]. For the purposes of this research, the groups by their semantic features especially for cultural placenames deem relevant for adding: people's activity (Бежеик < Russian 'to flee', referring to fugitives), ethnonyms (Germany, after the Germanic tribes), type of settlement (Вологда $<$ Veps 'white town') [Vasmer, 1986. C. 340]. The current classification added an additional group, miscellaneous, 
intended for the toponyms derived from other proper names as they are of primary naming unlike the other stems derived from appellatives in the classification. The semantic features presented with fewer than 4 appellatives were not included into the main classification either.

To accomplish the section, several terms applied in the research part deem relevant for additional explanation to avoid ambiguities. The terms for explaining are a semantic feature, toponymic appellative and choronym. Semantic feature is a generic trait comprised or identified in names, e.g. a feature of plants shown in the Spanish place-name Palma. Toponymic appellative is a word of general vocabulary which may determine motivation for a toponym, e.g. the Norwegian city of Bergen with the appellative berg meaning 'mountain'. The latter place-name also illustrates the term choronym, i.e. a "geographical name the semantic content of which presents a terrain feature" [Basik, 2006. P. 53], especially in contrast to a water feature.

\section{Research part}

The total number of the proper names made up 181 items in the discourses, which included 53 anthroponyms, 46 ethnonyms and 82 place names. The share of the place names proved to be the largest compared to the other proper names, such as anthroponyms. The latter group was subject to the etymological analysis in the discourses. The sources of the etymologies were the Polish, Czech, Serbian, Dalmatian and Swedish languages. The majority of the place names in Trediakovsky's book were macrotoponyms of international geography, namely, 3 continents, 8 geographical areas, 4 ancient states, 3 mountain ranges, 7 countries, and 22 hydronyms. The bulk of international toponymicon points to a feature of alternative etymology, i.e. foreign words are mostly subject to folk etymology [Dalberg, 2008. P. 81; Reformatsky, 1996. P. 111].

The majour semantic classification of the alternative etymology place-names consists of 7 groups including 85 appellatives. The appellatives with natural features accounted for 53 items $(62.3 \%)$ while the appellatives with cultural features comprised 32 items (36.4\%). The natural domain represented the following features: hydronym - 24 items $(28.2 \%)$; choronym -15 items $(17.6 \%)$; climate -9 items $(10.5 \%)$; and soil features -6 items $(7 \%)$. The cultural domain incorporated the features of people's activity -21 items ( $24.7 \%)$; ethnonym -6 items (7\%); and type of settlement -4 items $(4.7 \%)$. The place names which were sporadic in the selection related to fauna -2 items and flora -1 item. 4 out of 8 place names, names after other proper names,were of transferred naming pattern with the model: a city named after a nearby water feature: Pskov < Pskov Lake (known as Lake Peipus), Moscow < the Moskva, Lovosice < the Laba, Gdansk < Codanus sinus. 3 place names Caesaria, Sambat and the Moskva were derived from anthroponyms.

Every entry presented further, starts with the English form of a place name followed by the Russian form utilized by Trediakovsky, with the anglicized version of pronunciation given in brackets. The symbol < shows the hypothesized appellative with its English equivalent.

\section{Natural domain}

Hydronym: the Danube: Дунай (Dunay) < от глубины и тишины 'of depth and quietness'; the Dnieper: Днепр (Dnepr) < прущий со дна 'springing from the bottom'; the Dniester: Днестр (Dnestr) < днистый 'of a deep bottom'; the Don: Дон (Don) < от глубины и тишины 'of depth and quietness'; the Volga: Волга (Volga) < многовлажная 'water-rich'; the Gypanis: Гипань (Gipan') < купание 'bathing'; or < кипение 'bubbling'; the Borysthenes: Бористен (Boristen) < бори стеньл 'removing walls'; Дуйна (Duyna) < раздуваемая 'of blown' [waves]; the Rudon: Pyдон (Rudon) < красная 'red' [river]; Volnyj: Вольнипрах (Volnyprakh) < волненный порог 'wavy rapid'; Vyryuchy: Веручи (Vyryuchy) < вырю 'bubbling'; Iberia: Оберия (Oberia) < обёрнута 'surrounded' [with water]; Batavia: Водания (Vodaniya) < водная 'of water'; Pomerania: Поморие (Pomorie) < по морю 'by the sea'; Pskov: Блесков (Bleskov) < блеск 'shining' [water]; the Caledonian sea: Хладонское (Khladonskoe) (sea) < хладное 'cold', i.e. stretching to the North Sea; Ulvorsi: Пул-во-рци (Pul-vo-rtsi) < быстрая река 'fast-flowing river'; or: Гул-во-рци (Gulvo-rtsi) < гуляние and река 'free and river'; or Куль-во-рци (Kul-vo-rtsi) < быстрая река 'fast- 
flowing river'; or: Юль-во-рци (Yul-vo-rtsi) < быстрая река 'fast-flowing river'; the Kamenice: Камниц (Kamnits) < камень 'stone'; the Tetschen: Течень (Techen') < течь 'flow'.

Choronym: Africa: Оприка (Oprica) < опричная 'separated'; Spain: Выспания (Vyspania) < высnа (wyspa) 'peninsula'; Germany: Холмания (Kholmaniya) < холмы 'hills'; Norway: Наверхия (Naverkhiya) < наверху 'located above', i.e. northbound; Denmark: Дания (Daniya) < день 'day'; Sweden: Светия (Svetiya) < свет 'light'; Italy: Выдалия (Vydaliya) < выдалась 'stuck out' [into the Mediterranean sea]; Holstein: Колостиния (Kolostiniya) < кольцо 'ring', i.e. similar to a circular peninsula; Sicily: Сечелия (Secheliya) < отсеченная 'cut' from Italy; the Alps: Олбы (Olby) < лбы в круг 'surrounded with hills'; the Pyrenees: Пиренейские горы (Pireneyskie gory) < пирина 'lock'; the Elba: Эльба (Elba) < лоб 'hill'; Ulvorsy: Островунипрах (Ostrovuniprakh) < островной порог 'islet rapid'; Wagria: Вагрия (Vagriya) < горы 'mountains'; Holmgard: Гольмгардия - Холмогория (Kholmogoriya) < холмы и горы 'hills' and 'mountains'.

Climate: Asia: Азия (Aziya) < осияющее 'shining' [sun]; Siberia: Сибирь (Sibir') < северная 'northern'; Iberia: Ожижия (Ozhizhiya) < дождь 'raining'; Scandinavia: Шкодынавия (Shkodynaviya) < вред 'the harm' [brought from North]; Italy: Удалия (Udaliya) < удаленная 'remote' [from North]; Caledonia: Хладония (Khladoniya) < хладная 'cold' country; Lusitania: Лишедания (Lishedania) < лишенная дня 'without daylight'; the Viadrus: Виадра (Viadra) < ведро 'fair weather'; Wagria: Вахрия (Vakhriya) < вихрь 'whirlwind'.

Soil: Germany: Кормания (Kormaniya) < корм 'food'; or Ярмания (Yarmaniya) < ярмо 'охbow', i.e. a synecdoche for industrious and tireless in agriculture inhabitants; Saxony: Сажония (Sazhoniya) < сажать 'planting'; Helvetia: Голветия (Golvetiya) < голая страна 'naked land', i.e. of little arable land; Pskov: Песков (Peskov) < песок 'sand'; the Sava: Сава (Sava) < сев 'sowing'.

\section{Cultural domain}

People's activity: Europe: Европа (Evropa) < ярина 'spring cereals', i.e. as a comparison for fair hair; Belgium: Бельгия (Belgia) < белка 'white' [by colour]; Britain: Бродания (Brodaniya) < борода 'beard', Братания (Brataniya) < брат 'brother', Пристания (Pristaniya) < пристать 'embarking'; Desht-i Qipchaq, Cumania: Кафджак / Кипчак (Kafjak / Kipchak) < ковш 'scoop', a vessel worn by the inhabitants of Cumania; Aquitania: Охвытания (Okhvytania) < захваченная 'occupied' [in all directions]; Овитания (Ovitania) < обитать 'to be inhabited'; Окатания (Okatania) < катать 'to surround'; Batavia: Бодавия (Bodaviya) < прободение 'puncturing', i.e. characterizing eople good at thrusting weapon; Celtia: Целтия (Tseltiya) < жёлтая 'yellow' [by the skin colour]; Illiriya: Льюрикия (Iieurikiya) < льющаяся речь 'flowing speech'; the Tiras: Тиpac (Tiras) < тирас 'warrior'; Эссупи: Не супи (Ne supi) < не сnи 'do not sleep'; Volnyj: Варуво Poc (Varuvo Ros) < варове рос 'fast growing'; Wolin: Велин (Velin) < великий 'great' [people]; or < вольный 'free' [people]; Gelandri: Горла-на-дери (Gorla-na-deri) < горло надери 'to bawl'; Naprjazi: Непрязи (Nepryazy) < натягивать 'to pull' [a sail]; Срывун < натягивать 'to pull' [a sail]; Codanus sinus: Ходанский залив (Khodansky zaliv) < ходить в море 'to sail'; Latium: Ладий (Lady) < лад 'concord'.

Ethnonym: Prussia: Поруссия (Porussiya) < по руси 'by Rus'; Scythia: Скифия (Skifiya) < скифы 'Scythians'; the Tiras: Тирас (Tiras) < росский 'Russian'; the Ros (Rusnaite): Pyca (Rusa) < руссы 'Rus' people'; Ross: Pocc (Ross) < русский 'of Rus' people'; the Porusia: Порусья (Porusya) < no pycu 'by the Rus' people'.

Type of settlement: Mecklenburg: Моглоградия (Moglogradiya) < могущество and город 'might' and 'town'; the Caucuses: Кавказ (Kavkaz) < Гог Kou 'camp of Gog'; Holmgard: Гольмгардия (Golmgardiya) Холмогория (Kholmogoriya) < остров and город 'island' and 'town'; Gardariki: Градорекия (Gradorekiya) < множество городов 'multiple towns'.

Miscellaneous: Astrakhan: Астрахань (Astrakhan) < острый конь 'a sharp horse'; the Drava: Драва (Drava) < древо and трава 'wood or grass'; Nejasyti: Неясыт (Neyasyt) < пеликан 'pelican'; the Vistula: Висла (Wisla) < веселая 'merry'; the Neva: Нева (Neva) < новая 'new'; 
the Istros: Истарь (Istar') < старая 'old'; the Baltic sea: Балтийское море (Baltiyskoe more) < балда 'oval'.

The place names derived from proper names: Pskov: Псков (Pskov) < Псковское озеро 'Pskov lake' (known as Lake Peipus); Moscow: Москва (Moskva) < Москва-река 'the Moskva'; Lovosice: Лобощиц (Loboshits) < Лаба 'Laba'; the Volkhov: Волхов (Volkhov) < Волга 'Volga'; Gdansk: Ходанск (Khodansk) < Ходанский залив 'Codanus sinus'; Kayseri: Кесария (Kesariya) < Св. Василий Великий Кесарийский 'Saint Basil of Caesaria'; Sambat: Самбат (Sambat) < князь Самовит 'prince Samovit'; the Moskva-river: Москва-река (Moskva-reka) < Мосох 'Mosoch'.

As to the dictionary [Vasmer, 1986], the total number of place names collected in volume $1 \mathrm{ac}-$ counted for 148 items. Besides the place-names, the volume of the dictionary contained 59 anthroponyms and ethnonyms. The etymologies were derived from various languages, in particular Russian, Latin, Greek, German, Polish, and Swedish. The main selection used in the classification made up 61 items. Some features specified in the works on toponymics [Kuhn, 2016] were not included in the research due to insignificant numbers. They were flora accounting for 3 items, fauna, climate and religion numbering 2 items each. Additionally, it should be noted that the toponyms coined after proper names made up 46 items. The shares for natural and cultural domains accumulated 42 items, $68.8 \%$, and 19 items, $31.1 \%$, respectively. The place names were divided into 5 semantic feature groups which were hydronym and choronym for the natural domain, and people's activity, ethnonyms, and type of settlement for the cultural domain. The ratio for the semantic features from the dictionary can be represented in the following way:

Natural place names (63.6\%): hydronym - 27 items (44.2\%), e.g. Балxam (Balkhash) < Tatar 'swamp'; choronym - 15 items (24.5\%), e.g. Азов (Azov) < Turkish, Azak 'low place';

Cultural place names $(28.6 \%)$ : people's activity 8 items (13.1\%), e.g. Винница (Vinnitsa) < Polish 'distillery'; ethnonym - 5 items $(8.1 \%)$, e.g. Венден (Venden) < German 'Wenden'; type of settlement- 6 items (9.8\%), e.g. Аккерман (Akkerman) < Turkish 'white castle'.

To prove the hypothesis concerning the similarities of the semantic features in the etymological research, the classified place names and their shares were compared. Both selections of the two different periods were examined with a quantitative focus on place names among proper names: $82(45 \%)$ place names in the discourses and $148(71.4 \%)$ in the dictionary. The natural domain exceeded the cultural one in both selections: $63.5 \%$ in the discourses and $68.8 \%$ in the dictionary. The number of the features for the natural domain differed: 4 in the discourses and 2 in the dictionary, while the cultural domain was presented with 3 identical groups. The majority of the semantic features, 5 out of 7 groups, were presented in both selections: hydronym, choronym; people's activity, ethnonym and type of settlement. These 5 groups may be regarded as the core of the semantic features of the etymological place-name classification. The semantic features hydronym and choronym dominated proportionately with $45.8 \%$ in the discourses and $68.8 \%$ in the dictionary. The groups with the other semantic features specified in the semantic classification of Kuhn [Kuhn, 2016. P. 137-138] were found only in the discourses: soil $-7 \%$ and climate $-10.5 \%$. As to the cultural domain, the feature of people's activity dominated in both selections: $24.7 \%$ in the discourses and $13.1 \%$ in the dictionary. As for the transferred place names, which were not included in the majour classification, the number in the dictionary was significantly higher - 46 items, while the selection from the discourses made up 8 items.

Concerning the contrasting characteristics, the differences in the two selections were found in a larger number of place names, an extensive share of the place names derived from proper names in the dictionary is the selection based on the generally accepted in linguistics approach; the discourses - the selection based on alternative etymology - were presented with a greater number of semantic features. Still, the correspondence may be seen in the semantics comprised in the placename classification and the ratio of semantic features in both toponymicons. 


\section{Conclusion}

The paper shows that alternative etymology and the attempts to trace the origins of Russian words have had a lasting tradition in Russian historiography and enhances interest in etymology in Russia as well as the history of the Russian language in the $19^{\text {th }}$ century [Reyfman, 1990. P. 236]. It shows the trends in the development of alternative etymology. The research proved that the core group of semantic features in the place names remained similar despite a 200-year time span and showed the relevance of place names for the alternative etymological approach. The dominating semantic features utilized in the alternative approaches and comparative method correlated. The etymologies in the discourses were based mostly on the comparisons between words without considering grammar forms. Though heavily criticized, Trediakovsky's approach may have been acceptable when comparative linguistics only began developing scientifically in Russia at that time, with the comparative method being introduced in the $19^{\text {th }}$ century.

\section{References}

Basik, S. N. General Toponymics. A Manual of the Students of the Faculties of Geography. Minsk, BGU, 2006, 197 p. (in Russ.)

Dalberg, V. So-called Folk-etymological Reshaping of Place-names. In: Dalberg, V. Name and Place. Ten Essays on the Dynamics of Place-names. Copenhagen, University of Copenhagen, 2008, p. 80-93.

Eco, U. The Search for the Perfect Language (The Making of Europe). Oxford, Blackwell Publishing Ltd., 1995, 385 p.

Entwistle, W. S., Morison, W. A. Russian and the Slavonic Languages. London, Faber and Faber Limited, 1949, $407 \mathrm{p}$.

Hough, C. (ed.) The Oxford Handbook of Names and Naming. Oxford, OUP, 2016, $771 \mathrm{p}$.

Klubkov, P. A. The Etymologies of Trediakovsky as a Fact of Historical Linguistics. Humanitāro zinātyu vēstnesis Daugavpils universitāte, 2002, no. 2, p. 58-68. (in Russ.)

Kuhn, J. Rural Names. In: Hough, C. (eds.). The Oxford Handbook of Names and Naming. Oxford, OUP, 2016, p. 135-143.

Lomonosov, M. V. The Notes on the Dissertation of G.-F. Miller "The Origin of the Name and the People of Russia". In: Lomonosov, M. V. The Complete Works. Moscow, Leningrad, AS USSR Publ., 1952, vo. 6: The Works on Russian History, Social and Economic Issues and Geography, p. 17-80. (in Russ.)

Lyatsky, E. A. Trediakovsky. In: Brochaus, F. A., Efron, I. A. (eds.) Encyclopedic Dictionary, 33 A, Tombigbi - Quinisext Council. St. Petersburg, Brochaus-Efron, 1901, p. 750-753. (in Russ.)

Maltseva, T. V. On the Origin of the Russian People and Russian Language: Trediakovsky, Lomonosov, Sumarokov. Znanie. Ponimanie. Umenie, 2015, no. 3, p. 299-307. (in Russ.)

Maltseva, T. V. The Works on History Concerning the 'Most Important Russian Antiquities': Trediakovsky v Academics Supporting Normanism. Art Logos, 2019, no. 1, p. 120-126. (in Russ.)

Nadezhdin, N. I. An Essay on the Historical Geography of the Russian World. Biblioteka dlya chteniya, 1837, vol. 22, p. 27-79. (in Russ.)

Nosovsky, G. V., Fomenko, A. T. The Old Maps of the Great Russian Empire, Ptolemy and Ortelius in the Light of the New Chronology. Moscow, Astrel', AST, 2010, 685 p. (in Russ.)

Rastyagaev, A. V., Slozhenikina, Yu. V. The Genesis of Cultural and Political Mythology: Trediakovsky (1757), Lomonosov (1758), Sumarokov (1759) on the Origin of the Russian Nation and Russian Language. Russian Linguistic Bulletin, 2016, no. 1 (5), p. 36-37. (in Russ.)

Reformatsky, A. A. Introducing Linguistics. Moscow, Aspekt Press, 1996, 536 p. (in Russ.)

Reyfman, I. Vasilii Trediakovsky: The Fool of the "New" Russian Literature. Stanford, Stanford Uni. Press, 1990, 316 p. 
Schlözer, A. L. Nestor. Russian Manuscripts in the Old Slavic Language. St. Petersburg, Imperatorskaya tipografiya, 1809. (in Russ.)

Schoettgenius, Ch. De Ruthenorum originibus. Sectio III. In: Schoettgenius, Ch. De Originibus Russicis Dissertationes Septem. Dresdae et Lipsiae, Literis Harpeterianis, 1730, n. p.

Soloviev, S. M. Russian Historiographers of the $18^{\text {th }}$ Century. In: Soloviev, S. M. History of Russia since the Most Ancient Times. St. Petersburg, Obshchestvennaya pol'za, 1901, p. 1317-1388. (in Russ.)

Starchevsky, A. V. Trediakovskiy. In: The Essay on the Russian History before Karamzin, St. Petersburg, K. Zhernakov, 1845, p. 140-141. (in Russ.)

Taszycki, W. Slowianskie nazwy niejscowe (Ustalenie podzialu). Krakow, Polski Akademia Umiejetnosci, 1946, $64 \mathrm{p}$.

Tatishchev, V. N. By the Author Theophilus Siegfried Bayer De Varagis. In: Tatishchev, V. N. Complete Works. In 8 vols. Moscow, Ladomir, 1994, vol. 1: Russian History, pt. 1, p. 292310. (in Russ.)

Tent, J., Blair, D. Motivations for Naming a Toponymic Typology. ANPS Technical paper, 2009, vol. 2, p. 1-26.

Trediakovsky, V. K. Three Discourses on Three Most Important Russian Antiquities, namely: 1. On the Primacy of the Slavyansky Language to Teutonic. 2. On the Origins of the Rus' People. 3. On the Varangians as Slavic Russian People, their Title, Genesis and Language. In: Works. In 3 vols. St. Petersburg, Imperatorskaya Akademiya nauk, 1849, p. 319-540. (in Russ.)

Trediakovsky, V. K. Three Discourses on Three Most Important Russian Antiquities. Abriged ed. by V. N. Vasilev. Moscow, Belye al'vy, 2013, 216 p. (in Russ.)

Vasmer, M. Etymological Dictionary of the Russian Language. In Four Volumes. Volume 1 (AD). Moscow, Progress, 1986. 576 p. (in Russ.)

\section{Список литературы}

Басик С. Н. Общая топонимика: Учеб. пособие для студентов географического факультета. Минск: БГУ, 2006. 197 с.

Клубков П. А. Этимологии Тредиаковского как факт истории лингвистики // Humanitāro zinātnu vēstnesis Daugavpils universitāte. 2002. № 2. C. 58-68.

Ломоносов М. В. Замечания на диссертацию Г.-Ф. Миллера «Происхождение имени и народа Российского» // Ломоносов М. В. Полн. собр. соч. М., Ленинград: Изд-во АН СССР, 1952. Т. 6: Тр. по русской истории, общественно-экономическим вопросам и географии 1747-1764 гг. С. $17-80$.

Ляцкий Е. А. Тредьяковскій // Брокгауз Ф. А. и Ефрон И. А. (ред.) Энциклопедический словарь. СПб.: Брокгауз - Ефрон, 1901. 33 А, Томбигби - Трульский соборъ. С. 750-753.

Мальцева Т. В. О происхождении русского народа и русского языка: Тредиаковский, Ломоносов, Сумароков // Знание. Понимание. Умение. 2015. № 3. С. 299-307.

Мальцева Т. В. Исторические труды о «главных российских древностях»: В. К. Тредиаковский vs академические «норманисты» // Art Logos. 2019. № 1. С. 120-126.

Надеждин Н. И. Опыт исторической географии русского мира. Статья первая // Библиотека для чтения. 1837. Т. 22. С. 27-79.

Носовский Г. В., Фоменко А. Т. Старые карты Великой Русской Империи. Птолемей и Ортелий в свете новой хронологии. М.: Астрель: АСТ, 2010. 685 с.

Растягаев А. В., Сложеникина Ю. В. Генезис культурно-политической мифологии: Тредиаковский (1757), Ломоносов (1758), Сумароков (1759) о происхождении русской нации и русского языка // Russian Linguistic Bulletin. 2016. № 1 (5). С. 36-37.

Реформатский А. А. Введение в языковедение. М.: Аспект Пресс, 1996. 536 с.

Соловьёв С. М. Писатели русской истории XVIII века // Соловьёв С. М. История России с древнейших времён, СПб.: Общественная польза, 1901. С. 1317-1388. 
Старчевский А. В. Тредіаковскій // Старчевский А. В. Очерк литературы русской истории до Карамзина. СПб.: К. Жернаков, 1845. С. 140-141.

Татищев В. Н. Автора Феофила Сигефра Беера о варягах // Татищев В. Н. Собр. соч.: В 8 т. М.: Ладомир, 1994. Т. 1: История Российская. Ч. 1. С. 292-310.

Тредиаковский В. К. Три рассуждения о трех главнейших ценностях российских, а именно: 1. О первенстве словенского языка перед тевтоническим. 2. О первоначалии россов. 3. О варягах руссах славенского звания, рода, языка // Тредиаковский В. К. Соч.: В 3 т. СПб: Имп. Академия наук, 1849. Т. 3. С. 319-540.

Тредиаковский В. К. Три разсуждения о трех главнейших древностях Российских. Адаптированное переложение В. Н. Василева. М.: Белые альвы, 2013. 216 с.

Фасмер М. Этимологический словарь русского языка: В 4 т. М.: Прогресс, 1986. Т. 1 (А-Д). $576 \mathrm{c}$.

Шлёцер А. Л. Несторъ. Рускія льтописи на древле-славенскомъ языкъ. СПб.: Имп. типография, 1809. $476 \mathrm{c}$.

Dalberg, V. So-called folk-etymological reshaping of place-names. In: Dalberg, V. Name and place. Ten essays on the dynamics of place-names. Copenhagen, University of Copenhagen, 2008, p. 80-93.

Eco, U. The search for the perfect language (The making of Europe). Oxford, Blackwell Publishing Ltd, 1995, $385 \mathrm{p}$.

Entwistle, W. S., Morison W. A. Russian and the Slavonic languages. London, Faber and Faber Limited, 1949, $407 \mathrm{p}$.

Hough, C. (ed.) The Oxford handbook of names and naming. Oxford, OUP, 2016, $771 \mathrm{p}$.

Kuhn, J. Rural names. In: Hough, C. (ed.). The Oxford handbook of names and naming. Oxford, OUP, 2016, p. 135-143.

Reyfman, I. Vasilii Trediakovsky: The fool of the "new" Russian literature. Stanford, Stanford Uni. Press, 1990, $316 \mathrm{p}$.

Schoettgenius, Ch. De Ruthenorum originibus. Sectio III. In Schoettgenius Ch. De originibus russicis dissertationes septem. Dresdae et Lipsiae, Literis Harpeterianis, 1730, n. p.

Taszycki, W. Slowianskie nazwy niejscowe (Ustalenie podzialu). Krakow, Polski Akademia Umiejetnosci, 1946, 64 p.

Tent, J., Blair, D. Motivations for naming a toponymic typology. ANPS Technical paper, 2009, no. 2, p. 1-26.

Date of submission Материал поступил в редколлегию 02.09.2020

\section{Information about the Author / Сведения об авторе}

Alexander V. Kalashnikov, Cand. of Sci. (Philology), Associate Professor, School of Foreign Languages, Faculty of Human Sciences, National Research University Higher School of Economics (Moscow, Russian Federation)

Калашников Александр Владимирович, кандидат филологических наук, доцент школы иностранных языков, факультета гуманитарных наук, Национальный исследовательский университет «Высшая школа экономики» (Москва, Россия)

avkalashnikov@hse.ru

ORCID 0000-0002-2909-9994

SPIN-код 2647-0380 